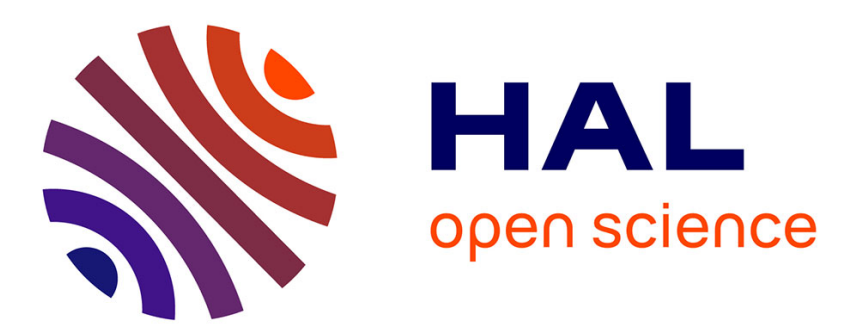

\title{
Numerical investigation of transient hydrothermal processes around intrusions: heat-transfer and fluid-circulation controlled mineralization patterns.
}

Khalifa Eldursi, Yannick Branquet, Laurent Guillou-Frottier, Eric Marcoux

\section{- To cite this version:}

Khalifa Eldursi, Yannick Branquet, Laurent Guillou-Frottier, Eric Marcoux. Numerical investigation of transient hydrothermal processes around intrusions: heat-transfer and fluid-circulation controlled mineralization patterns.. Earth and Planetary Science Letters, 2009, 288 (1-2), pp.70-83. 10.1016/j.epsl.2009.09.009 . insu-00413813

\section{HAL Id: insu-00413813 \\ https://hal-insu.archives-ouvertes.fr/insu-00413813}

Submitted on 7 Sep 2009

HAL is a multi-disciplinary open access archive for the deposit and dissemination of scientific research documents, whether they are published or not. The documents may come from teaching and research institutions in France or abroad, or from public or private research centers.
L'archive ouverte pluridisciplinaire HAL, est destinée au dépôt et à la diffusion de documents scientifiques de niveau recherche, publiés ou non, émanant des établissements d'enseignement et de recherche français ou étrangers, des laboratoires publics ou privés. 


\section{Numerical investigation of transient hydrothermal processes around intrusions: heat-transfer and fluid- circulation controlled mineralization patterns.}

Khalifa Eldursi ${ }^{1}$, Yannick Branquet ${ }^{*}{ }^{*}$, Laurent Guillou-Frottier ${ }^{2}$, Eric Marcoux ${ }^{1}$

1. Université d'Orléans et Université François Rabelais de Tours / CNRS / INSU, ISTO UMR 6113, Campus CNRS, 1A rue de la Férollerie, 45071 Orléans Cedex, France.

2. Bureau de Recherches Géologiques et Minières, 3 avenue Claude Guillemin, BP 36009, Orléans, F45060, Cedex 2, France.

*Corresponding author: yannick.branquet@,univ-orleans.fr 


\begin{abstract}
New insights on the circulation of fluids around magmatic intrusions have been obtained through coupled hydrothermal numerical modelling that takes into account i) a continuous variation of permeability with depth, ii) the period of intrusion emplacement, iii) the physical likelihood of ore deposition using a restricted rock alteration index, and iv) the so-far unexplored pluton floor, and then comparing the results against well-constrained natural cases showing different emplacement depths, high permeability zones (cracked thermal aureoles), faults and plutonic apexes. We show that emplacement depth is a key physical parameter controlling the extent and geometries of advective heat dissipation zones, and that shallow apexes strongly modify the fluid-flow pattern by acting as a focus for convective fluids and mineralization zones. We also show that the cooling phase is not the main convective phase for large plutons commonly associated with long-lived magma emplacement; major advective heat dissipation and mineral deposition zones may also develop before and during the hottest phase of the emplacement, i.e. before magma crystallization. The comparison with natural cases shows that we successfully reproduce, in space and time, the physical conditions required for mineral deposition. In particular, extensional detachment is able to restrain and modify classical fluid-flow patterns induced by coeval intrusion. Finally, even though lacking chemical arguments, we conclude that convection induced by granite emplacement plays a major role in the genesis of granite-related Au deposits. Moreover, the formation of this type of deposit is favoured and controlled by the presence of a fractured thermal aureole around the intrusion.
\end{abstract}

Keywords: Hydrothermal processes, numerical modelling, magmatic intrusion, permeabilitydepth curve, mineralization, rock alteration index. 


\section{Introduction}

Despite extensive studies of the hydrodynamics around intrusions the circulation of hot and variably pressurized fluid in the uppermost kilometres of the crust is still not easily predictable. This is because rock and fluid properties can show large time- and/or depthdependent variations around such geological systems. For example, the complexity of such systems is confirmed by work on the reactions of metamorphic minerals and distribution of stable light isotopes around natural aureoles (Ferry and Dipple, 1992; Nabelek and Labotka, 1993; Dipple and Ferry, 1996; Ferry et al. 1998; Ferry et al., 2002; Rossetti et al., 2007). Controversial 1D models derived from some of these studies have difficulty in tracing periplutonic transient flow patterns in detail.

A pluton's host rock has a permeability threshold above which heat dissipation during the system's cooling is achieved by fluid advection rather than conduction. The value of this threshold for homogenous country rock spans an interval of $10^{-16}-10^{-18} \mathrm{~m}^{2}$ (Norton and Knapp 1977; Norton and Knight 1977; Gerdes et al. 1998; Cui et al. 2001), which is easily reached at a few kilometres depth (e.g. Ingebritsen and Manning, 1999). Hot plutons also create density gradients in the country rock, along with long-lived $\left(>10^{5}\right.$ years with rapid magma emplacement) large-scale regional flows (Cathles 1977; Norton and Knight 1977; Cook et al. 1997). Consequently, it has been suggested that the heated fluids are responsible for the development of large convection cells around the intrusion; Norton and Knight (1977) have even quantified a very large amount of fluid involved in convection cells far from the pluton. Moreover, magmatic brines expulsed from the intrusion will increase fluid salinities and thus enhance buoyancy forces. However, the production of magmatic and metamorphic fluids constitutes a pressure-driven force that interacts with buoyancy forces; for example, Hanson (1992, 1995) and Manning and Ingebritsen (1999) show that below the critical permeability threshold of $10^{-16} \mathrm{~m}^{2}$, fluid-production forces trigger supra-hydrostatic fluid pressures and dominate density-driven forces.

The last 15 years have seen the development of a series of improved numerical models concerning the physics and chemistry of 2D and 3D hydrothermal systems (e.g. Hayba and Ingebritsen, 1997; Wilcock, 1998; Fontaine et al., 2001; Coumou et al., 2006; Kühn et al., 2006). The most elaborated numerical codes now include the possibility of simulating multicomponent, multi-phase flow with non-linear fluid properties and time-dependent 
permeabilities, within a three-dimensional geometry (e.g. Clauser, 2003; Xu et al., 2004; Kipp et al., 2008).

Regional metamorphic fluid flow and large-scale structures (i.e. folds, faults, regional cleavage, etc.) are considered to be the first-order controls on a bulk flow pattern, with plutons acting only as second-order perturbations (e.g. Stern et al., 1992; Wing and Ferry, 2002). Nevertheless, it is precisely the second-order perturbations (i.e. anomalies) of fluidflow patterns that are assumed to be important factors during ore-deposit genesis. It has been demonstrated, ever since the pioneering work of De Launay (1913), that magmatic intrusions play an active role in the depositional processes of ore and raw materials (e.g. Sillitoe, 1991; Thompson and Newberry, 2000; Lang and Baker, 2001; Cerny et al., 2005; Carr et al., 2008). The role of an intrusion in ore deposition will vary according to deposit type. We can distinguish, for example, i) a strong role characterized by a genetic chemical and mineralogical link between the intrusion and the ore (e.g. $\mathrm{Ni}-\mathrm{Cu}$ sulphide deposits within mafic-ultramafic magmas; Arndt et al., 2005), ii) an intermediate role, where it is wellestablished that part of the mineralizing fluids is magma derived (e.g. Au-Cu-Mo porphyries; Seedorf et al., 2005), and iii) a limited and/or indirect role where chemical arguments for a magmatic connection are lacking or equivocal-for example, non-porphyry intrusion-related Au-Sn deposits show very subtle links with magmatic fluids (Thompson et al., 1999). Indeed, even if Baker and Lang (2001) suggest a predominant magmatic origin for some of these ore deposits, the signature of the ore-forming fluids is commonly difficult to establish unequivocally. In this respect, heat transfer and fluid flows around magmatic intrusions appear to be of major importance in studying the temporal features of intrusion-related ore deposits (e.g. Cathles, 1981; Driesner and Geiger, 2007).

For the present study, we re-examined fluid-flow patterns around specific intrusions in order to delineate the most favourable zones for ore deposition as defined by dynamic criteria. Our numerical simulations (using coupled transient heat and fluid-flow equations) deal only with fluid convection triggered by the emplacement of a heat source (i.e. a pluton). By excluding fluid production and solute transport, we designed our models to highlight and test for significant points and hypotheses generally ignored in previous work. Since we use a pressure-temperature field where depths are between 1 and $15 \mathrm{~km}$ and temperatures are below $450{ }^{\circ} \mathrm{C}$, fluid properties of pure liquid water can be assumed.

First of all, we developed five theoretical models (M1 to M5) to explore the fluid-flow pattern immediately below the intrusion (see also Carr et al., 2008), close to the floor zone, since it stands to reason that the floor zone within a thermally equilibrated crust will not be a 
horizontal mirror image of the roof zone. Moreover, because we consider the magma ascent through a dyke-propagation mechanism (Clemens and Mawer, 1992), the thermal structure of crust below the pluton will presumably be less disturbed than in a diapiric-type ascent. Secondly, because our theoretical models are scaled to simulate large plutons within a $24-\mathrm{km}$ thick continental crust, we applied the permeability-depth curve of Manning and Ingebritsen (1999) (Fig. 1A), rather than a uniform, layered or stochastic permeability model (Norton and Knight, 1977; Gerdes et al., 1998); the introduction of a depth-dependent permeability model could have an important impact on the fluid-flow patterns. Thirdly, we have attempted to evaluate the ore-deposition potential using an improved version of the Rock Alteration Index (RAI) concept as defined by Phillips (1991) and used by others (Zhao et al., 1998; Gow et al., 2002; Harcouët, 2005), and then comparing our results to a selection of natural wellconstrained intrusion-related mineral deposits (models M6 to M11). Fourthly, earlier fluidflow models (see references above) only modelled the cooling phase without taking account of either the emplacement phase (heating period) or the crystallization phase (a quasiisothermal period); even though this assumption may be valid for small shallow intrusions (emplacement of less than 100,000 years; Petford et al., 2000), melt production and pluton emplacement can occur over several million years (e.g. by stacking of sills) in collision settings with no mantle contribution (Annen et al., 2006). Such duration estimates and emplacement mechanisms are currently debated, as for example in the Michaut and Jaupart (2006) study, where latent heat release due to crystallization leads to catastrophic heating of the magma pile and may last 1 Myr. Consequently, in the present study, we modelled sequential emplacement and subsequent cooling in order to depict the fluid-flow patterns from the stage of incipient pluton inflation to that of thermal re-equilibration into the crust. The possible effects of the intrusion shape, the emplacement depth and the role of stocks and permeable zones (such as fractures and/or faults) were evaluated and related to the hydrodynamics, the duration of the hydrothermal system and the mineralization potential.

\section{Intrusion-related ore deposits: tested natural examples}

As mentioned above, several well-constrained intrusion-related ore and raw-material deposits were selected for depicting the influence of various factors on the hydrodynamics of such systems (Fig. 1).

The Boboras pluton ( $318 \pm 5 \mathrm{Ma})$ and associated Bruès gold deposit located within the internal zone of the Spanish Hercynian belt of Galicia (Fig. 1B) were selected to test the role 
of a fractured thermal aureole associated with a deep-seated intrusion (data from Gloaguen et al., 2003; Gloaguen, 2006). The age of the gold mineralization is uncertain (potential regional thermal resetting), but the structural controls and fluid inclusions argue strongly for a coeval genetic link between the granite emplacement and the mineralizing event. The host mica schist is strongly veined (partly mineralized) within the thermal aureole.

Fluid expulsion from the pluton may have caused hydraulic fracturing within the thermal aureole, which would then form a high permeability zone. Note that the Bruès gold deposit is located in the roof zone around the northern edge of the pluton and above a root zone. The deposit is characteristic of a deep-seated intrusion-related Sn-W Province gold deposit as defined by Thompson et al. (1999) and Lang and Baker (2001).

Natural examples of intrusion-related ore deposits associated with plutonic apexes were also selected to depict the potential role of apexes. The Scheelite dome gold deposit (Fig. 1C) is a well-established case of an intrusion-related gold deposit around and co-genetic with an apical granitic stock in a Sn-W Province (Baker and Lang, 2001; Stephens et al., 2004; Mair et al., 2006). As with the Boboras pluton, the thermal aureole at the apex is intensely fractured and veined. The emplacement of the intrusion and mineralization occurred between 94 and $92 \mathrm{Ma}$.

For a typical porphyry-type mineralization (Fig. 1C), we selected the famous Grasberg $\mathrm{Cu}-\mathrm{Au}$ porphyry in the Irian-Jaya fold and thrust belt (Pollard et al., 2005). The emplacement, from the first intrusive phase to the last mineralizing event, occurred between 3.4 and 3.0 Ma. The Kucing Liar Cu-Au skarn (3.4 Ma) along the Indenberg thrust, is coeval with an incipient intrusive phase of the Grasberg complex. When modelling the Scheelite dome and Grasberg deposits, we applied a realistic size (i.e. $10 * 2.5 \mathrm{~km}$ ) for the main underlying plutonic body (i.e. the upper crustal 'batholith').

Being a high permeability zone, a detachment fault may play an important role in channelling mineralizing fluid during an extensional regime. We were thus interested in exploring the fluid-flow pattern around plutons emplaced during low-angle extensional faulting. The geometries and structures of the Monte Capanne pluton and La Crocetta deposit along the Elba central detachment is a well-constrained example of such a system (Fig. 1D, data compiled from Bouillin et al., 1993; Maineri et al., 2003; Rossetti et al., 2007). La Crocetta is an important economic concentration of ceramic raw materials resulting from strong hydrothermal alteration associated with the emplacement of the Monte Capanne pluton. The emplacement and the sericitization at La Crocetta occurred between 7 and $6.8 \mathrm{Ma}$. 
It is noteworthy that the hydrothermal activity and mineralization at all the tested deposits occurred within 2 Myr of magma emplacement. Moreover, with the exception of the Grasberg porphyry system, the mineralizing fluids were not of pure magmatic origin, but reflect a mixing of different sources.

\section{Hydrothermal modelling: the governing equations and parameters}

The mass conservation equation for a fluid of variable density within a fluid-saturated porous medium (rock matrix) without an internal fluid source is

$$
\frac{\partial(\phi \cdot \rho)}{\partial t}=-\nabla \cdot(\rho \cdot \vec{u})
$$

where $\phi$ is the porosity, $\rho_{f}$ the fluid density, $t$ the time and $\vec{u}$ the fluid velocity vector (see Table 1 for units). The fluid is assumed to be incompressible with a constant chemical composition, and its density is temperature dependent. Darcy's law was used to describe the fluid velocity field:

$$
\vec{u}=-\frac{K}{\mu}(\vec{\nabla} p-\rho \vec{g})
$$

where $K$ is the intrinsic permeability, $\mu$ the dynamic fluid viscosity, $p$ the fluid pressure, and $\vec{g}$ the gravitational acceleration vector. The permeability was varied with depth, using Manning and Ingebritsen's (1999) equation:

$$
\log (K)=-14-3.2 \log (Z)
$$

where $Z$ is depth expressed in $\mathrm{km}$.

The fluid density varies linearly with temperature:

$$
\rho=\rho_{0}\left(1-\alpha_{v}\left(T-T_{0}\right)\right)
$$

where $\rho_{0}$ is the fluid density at room temperature $T_{0}$, and $\alpha_{v}$ the volumetric coefficient of thermal expansion of the fluid.

Based on an analytical approximation for the relationship of viscosity with temperature T (Kestin et al., 1978; Rabinowicz et al., 1998), the fluid dynamic viscosity is given by:

$$
\mu=2.41410^{-5} \cdot 10^{\left(\frac{247.8}{T-140}\right)}
$$

where $T$ is in $\mathrm{K}$ and $\mu$ in Pa.s. As illustrated by Clauser (2006) any pressure dependence of the viscosity can be ignored when compared with the temperature dependence. Heat transport is 
achieved by both conduction and advection in a porous medium, and is described for an incompressible, one-component, single fluid phase by:

$$
Q=C_{e q}\left(\frac{\partial T}{\partial t}\right)+\nabla \cdot\left(-\lambda_{e q} \vec{\nabla} T\right)+C_{L} \vec{u} . \vec{\nabla} T
$$

where $Q$ is the heat source provided by the pluton, $C_{L}$ is the volumetric heat capacity ( $C_{L}=\rho_{f} . C p$, with $C p$ being the specific heat capacity) and $C_{e q}$ and $\lambda_{e q}$ are the weighted average volumetric heat capacity and equivalent thermal conductivity, respectively, as defined in saturated porous media:

$$
C_{e q}=\phi \rho_{f} C p_{f}+(1-\phi) \rho_{s} C p_{s}
$$

where $f$ and $s$ are subscripts for fluid and country rock. The equivalent thermal conductivity is written as:

$$
\lambda_{e q}=\phi \lambda_{f}+(1-\phi) \lambda_{s}
$$

where $\lambda_{f}$ and $\lambda_{s}$ are the thermal conductivities of the fluid and the country rock.

Fluid flow and heat transport are coupled through the fluid's density and viscosity (Equations 4 and 5). Variations in fluid density with temperature affect both Darcy's law (through the buoyancy term) and the heat equation (through variations of $C_{e q}-$ see Equation 7), so that local density changes can affect the flow field. Among the chosen fluid properties, density, viscosity, heat capacity and thermal conductivity vary only with temperature, since pressure-dependence terms can be ignored for the first approximation.

\section{Defining a Restricted Rock Alteration Index}

Coupling the heat and fluid-flow equations was computed numerically using temperaturedependent properties and depth-dependent permeability. In order to gain some insight into how mineralization patterns can be deduced from the thermal and velocity fields, one can start from the initial work of Phillips (1991). In short, fluids carrying dissolved chemical species move through a permeable matrix or fracture network. In many geological situations, the controlling factor is the rate at which the reactants in solution can be delivered to the reaction site by advection and diffusion. As initially demonstrated by Wood and Hewett (1982), the dissolution/precipitation of an aqueous mineral is mainly dependent on advection, diffusive processes being negligible when large-scale processes (i.e. fluid circulation over a large timescale) are considered. 
As in buoyancy-driven convective flows, the fluid pressure gradient is small, and the mineral dissolution/precipitation rate depends on the scalar product of the fluid velocity vector by the temperature gradient (for more details see Phillips, 1991; Zhao et al., 1998; Raffensperger and Vlassopoulos, 1999; Zhao et al., 2001, 2003; Harcouët, 2005; HarcouëtMenou et al., 2009). This scalar is called the Rock Alteration Index (RAI) and in the case of a single fluid component, can be written:

$$
R A I \approx \vec{u} \cdot \vec{\nabla} T
$$

When several fluid components are considered, the RAI expression (according to Phillips, 1991) should be multiplied by the partial derivative of the mineral concentrations with temperature. Since mineral solubility is assumed to increase with temperature, Phillips (1991) deduced that if $\vec{u} \cdot \vec{\nabla} T$ is positive (resp. negative), then mineral dissolution (resp. precipitation) occurs. Since RAI unit (as defined in Equation 9) is $\mathrm{K}^{-1}{ }^{-1}$, we interpret negative RAI values as local cooling rates of the fluid, and positive values as local heating rates.

During regional metamorphism, a pluton gives rise to intense second-order fluid-flow perturbation within the slower regional fluid flow (Stern et al, 1992); for active regional metamorphism, a Darcy velocity of $10^{-11} \mathrm{~m} . \mathrm{s}^{-1}$ is considered to be an average value (Ingebritsen and Manning, 1999). During contact metamorphism, Darcy velocities, from timeintegrated fluxes based on mineral reactions and stable isotope studies, range from $10^{-9} \mathrm{~m} . \mathrm{s}^{-1}$ to $10^{-11} \mathrm{~m} . \mathrm{s}^{-1}$ (Ferry et al., 2002). Hydrothermal numerical models of contact or regional metamorphism predict Darcy velocities ranging from $10^{-8} \mathrm{~m} \cdot \mathrm{s}^{-1}$ to $10^{-11} \mathrm{~m} \cdot \mathrm{s}^{-1}$ (Cook et al., 1997; Gerdes et al., 1998; Oliver et al., 2006). Thus, in order to decipher the pluton contribution to fluid flow, a restricted fluid-velocity condition $\left(u>10^{-10} \mathrm{~m} . \mathrm{s}^{-1}\right)$ was added to the RAI. This restricted RAI $\left(\mathrm{R}^{2} \mathrm{AI}\right)$ is defined by:

$$
R^{2} A I=\left\{\begin{array}{l}
1 \quad \text { if } R A I<0 \text { and } u>10^{-10} \mathrm{~m} \cdot \mathrm{s}^{-1} \\
0 \quad \text { if } R A I>0 \text { or } u<10^{-10} \mathrm{~m} \cdot \mathrm{s}^{-1}
\end{array}\right.
$$

This definition corresponds to a parameter which is valid at a given time step.

To look at its temporal variation, since fluid velocities can exceed $10^{-10} \mathrm{~m} . \mathrm{s}^{-1}$ for only short periods of time one computes a kind of time-integrated $\mathrm{R}^{2} \mathrm{AI}\left(\mathrm{TR}^{2} \mathrm{AI}\right)$ which shows temporal variations of the $\mathrm{R}^{2} \mathrm{AI}$ for a given time period. Areas with a $100 \%$ (resp. $50 \%$ ) value correspond to zones where the $\mathrm{R}^{2} \mathrm{AI}$ equals 1 during all (resp. half of) the specified time period. 


\section{Model construction: geometry, timing, boundary conditions and rock properties}

\subsection{Geometry}

We constructed our models based on theoretical principles and also on selected well-known natural cases (M1 to M11, Fig. 2). The theoretical models (M1 to M5) were performed along the Manning and Ingebritsen (1999) depth-permeability curve. The basic model geometry was a rectangle, $2.5 \mathrm{~km}$ thick and $10 \mathrm{~km}$ wide, and the emplacement depths extended from 3 to $16.5 \mathrm{~km}$ (Figs. 1 and 2).

The natural case models (M6 to M11, Fig. 2) were adapted to selected natural examples (Fig. 1B, C, and D). The modelled plutons range from 25 to $31 \mathrm{~km}^{2}$ in size and their roofs lie within a depth range of 8 to $10 \mathrm{~km}$. For the continental crust, we used a 2D model geometry $47 \mathrm{~km}$ wide and $24 \mathrm{~km}$ deep (Fig. 2). The geometries of the pluton apexes, fractured aureoles and surrounding faults are described in Figure 2.

\section{$5.2 \quad$ Timing}

Our transient models were designed to take into account the time of emplacement and crystallization before cooling (see Introduction). The total duration of the numerical experiments is 20 Myr broken down as follows:

i) $\quad 0$ to $7 \mathrm{Myr}$. The initial imposed (a priori) thermal state evolves by adjusting the thermal and pressure fields to the effective boundary conditions and material's temperature-dependent properties;

ii) 7 Myr. Steady-state is considered as achieved since the temperature field no longer evolves significantly and averaged fluid velocities are around $10^{-16} \mathrm{~m} / \mathrm{s}$;

iii) 7 to $10 \mathrm{Myr}$. The duration of emplacement and crystallization, represented by a time-varying heat source, lasts $3 \mathrm{Myr}$ and includes two distinct phases - the heating period and the crystallization period, during which magma temperature is presumed to remain constant (including the effect of latent heat of crystallization). This time-varying heat source is set at $500 \mathrm{~mW} \cdot \mathrm{m}^{-3}$ with a condition that the magma temperatures do not exceed $700{ }^{\circ} \mathrm{C}$. As soon as the magma temperature reaches $700{ }^{\circ} \mathrm{C}$, the heat source is turned off. This high heat production value has no physical meaning since it is only used to increase 
the magma temperature for a given time period. To avoid sharp temperature differences, the beginning of the heating period is multiplied by a smoothing function.

The maximum temperature within the intrusion remains constant until the end of the emplacement-crystallization period at $10 \mathrm{Myr}$, which is here termed the hottest phase for the bulk model.

iv) 10 to $20 \mathrm{Myr}$. The subsequent cooling phase lasts $10 \mathrm{Myr}$, after which thermal equilibrium is re-established.

\subsection{Boundary conditions and rock properties}

The model's upper boundary represents the flat surface topography, which is permeable and maintained at $20^{\circ} \mathrm{C}\left(\mathrm{T}_{0}\right)$. The bottom is located at $24 \mathrm{~km}$ depth with the temperature fixed at $700{ }^{\circ} \mathrm{C}$. The lateral boundaries are assumed to be impermeable and thermally insulated. The initial temperature profile inserted into the model is:

$$
T=20+0.024 * z
$$

where $T$ is the temperature in ${ }^{\circ} \mathrm{C}$ and $z$ the depth in $\mathrm{m}$.

For simplification, the host rock is assumed to be a homogeneous saturated porous medium (constant porosity $=5 \%$ ) with a depth-dependent permeability (Equation 3 ), whereas the intrusion has the physical characteristics of granite (Table 1). As magma is considered as impermeable material (Gerdes et al. 1998), we fixed the permeability of the intruded body at $10^{-24} \mathrm{~m}^{2}$ during the emplacement period from 7 to $10 \mathrm{Myr}$. Before and after emplacement, the pluton permeability follows the depth-permeability curve.

Faults (Figs. 1 and 2) are modelled with a constant permeability (K value of $10^{-15} \mathrm{~m}^{2}$ ), whilst fractured aureoles around the pluton are considered as transient permeable zones activated ( $\mathrm{K}$ value of $10^{-15} \mathrm{~m}^{2}$ ) from 9.5 to $12 \mathrm{Myr}$. Before and after this time span, the permeability of the aureole zone follows the depth-permeability curve.

Our 2D models include a single homogenous fluid phase (pure water) so as to enable comparison with published models. Finally, the coupled models are built using a commercial finite-element code (Comsol Multiphysics ${ }^{\mathrm{TM}}$ ), which has been tested with various other configurations already published (see below). 


\section{Fluid-flow patterns: results and discussion}

\subsection{Benchmark}

The example shown in Figure 3 is taken from Gerdes et al. (1998) who resolve the transient hydrothermal circulation during pluton cooling. We reproduced their work after fitting the most probable bottom thermal boundary condition, and it can be seen (Fig. 3) that the results of this model match those from the published study. We also reproduced results obtained by Rabinowicz et al. (1998), in which higher permeabilities were involved. Identical unsteadyand steady-state convective patterns were obtained within a rectangular box with permeabilities of $10^{-15} \mathrm{~m}^{2}$ and $510^{-15} \mathrm{~m}^{2}$, respectively. Surface heat-flow values and variations were also recovered for these two last cases.

\subsection{Spatio-temporal evolution of the fluid-flow pattern and heat transfer}

Just before the emplacement, at $6.9 \mathrm{Myr}$, heat transfer by advection is negligible since fluid velocities are less than $10^{-16} \mathrm{~m} \cdot \mathrm{s}^{-1}$. As outlined in Section 5.2, a hydrostatic and a nearly steady-state thermal regimes are established.

To estimate the efficiency of the thermal advection, we computed a local Peclet number $(\mathrm{Pe})$, which compares thermal advection to thermal diffusion (Fig. 4). The critical Peclet number above which the influence of heat advection becomes significant is 1 .

Early during the magma emplacement (e.g. at 8 Myr on Fig. 4), the fluid flow patterns obtained within the pluton roof area correspond to those observed during the cooling phase in previous studies (e.g. Norton and Knight 1977): fluids inside the host rock migrate toward the upper corners of the pluton and create two convection cells above the intrusion. The cell on the left side is anticlockwise (Fig. 4), and that on the right side is clockwise. The pluton floor zone is characterized by a convergent fluid flow from both deep and shallow zones. Thus convection cells around the pluton may be triggered very early, even at the initiation of magma injection.

For shallow intrusions, the streamlines and isotherms are disturbed by a second-order convective instability above the pluton roof (M1 and M2 in Fig. 4a). This is well expressed in Figure 5, where the horizontal component of the fluid velocity shifts from a positive to a negative value through four convective half cells. These second-order convective cells depend on the pluton's length and emplacement depth, and may be important when considering mineralization potential. Moreover, mapping the $P e$ number for shallow to intermediate plutons indicates that advective heat dissipation is still dominant $10^{5}$ years after the hottest 
phase. The main convective discharge zone appears to be the area above plutons and represents the most advective zone (Fig. 4). For M1 to M4, this major discharge zone records the fluid velocity maxima, i.e. up to $10^{-8} \mathrm{~m} / \mathrm{s}$ at the hottest phase of M1.

As to be expected, the extent of the advective zones and $P e$ maximum values for all emplacement depths are greatest during the hottest phase (i.e. $10 \mathrm{Myr}$ ). This constitutes an important difference with models testing only the pluton's cooling phase (e.g. Norton and Knight, 1977). Moreover, since maximum buoyancy forces occur at the hottest phase and around the pluton borders for all the models, divergent buoyant fluids at the pluton contact yield the highest $P e$ along the pluton's lateral borders and corners (e.g. M4 in Fig. 4b). For intermediate to deep plutons (M3 to M5), when discharge zones above pluton are not established through time, the maximum fluid velocities are still encountered along the pluton borders. Consequently, although the heat transfer is only conductive for deep-seated plutons (M5 in Fig. 4b), abnormal fluid velocities might locally be reached along the pluton borders.

\subsection{Influence of emplacement depth}

For shallow intrusions (model M1 in Fig. 4a) one notes four convective cells (Fig. 5), as against none for the very deep intrusions (M5). In addition, maximum fluid velocities in the models decrease with increasing emplacement depth of the pluton. Also the formation of an apical discharge zone above the pluton is effective until the emplacement depth is around 10 km (i.e. M4 in Fig. 4b). The $P e$ distribution (Fig. 4) shows that the extent of the advective heat zone does not decrease with emplacement depths between 2 and $10 \mathrm{~km}$. It is also noteworthy that the advective heat transfer zone is not restricted around the pluton with increasing emplacement depth (M1 to M4 in Fig. 4), suggesting that supra-crustal plutons emplaced at depths above $10 \mathrm{~km}$ are able to induce extensive advective heat dissipation up to the surface. Conversely, $P e$ maxima decrease with increasing emplacement depth (from 24.5 in M1 to 12 in M4).

All these features are clearly related to variations in the host-rock permeability, which is depth-dependent in our models. As thermal transfer in M5 is only achieved through conduction, a permeability threshold below $7.10^{-18} \mathrm{~m}^{2}$ (around $10 \mathrm{~km}$, see Fig. 1A) is indicated for thermal advection. Another consequence of the permeability decrease with emplacement depth is the reduction of the thermal advective zone located beneath the pluton. 


\subsection{Apex effects}

To study the effects of added plutonic apexes, models M3, M7 and M9, all with the same emplacement depth $(8 \mathrm{~km})$, were compared during the intrusion emplacement phase (Fig. 4). No significant apex effect was observed where the apex is located in the deep zone of host rock (M7 in Fig. 4b). In contrast, where the apex extends into the shallow zone of the host rock (M9 in Fig. 4b) it disturbs the movement of the fluid around main intrusive body by relocating convective cells and discharge zones along and above the apex itself.

As we have considered the magma itself to be an impermeable zone, the fluids rise and accumulate at the highest point of the magma body (which is commonly a stock); we relate this to the fact that the permeability is higher in the shallow zones (near the highest point of the magma morphology). As apexes reach and extend into the shallow zones, effective advection is initiated along the apex borders during the magma emplacement phase and before the hottest phase (e.g. M9 at 8 Myr in Fig. 4b).

\section{Probable mineralization patterns vs. natural cases}

To study the effects of fractured aureoles and faults, therefore, we show the $\mathrm{R}^{2} \mathrm{AI}$ patterns (Equation 10) of models M1 to M4 and M7 in Figure 6. Also, for the tested natural cases of well-known ore deposits (M6, M8, M10 and M11) we depict the evolution of the mineralization potential from the phase of incipient magma emplacement to that of cooling, and show the distribution of the $\mathrm{TR}^{2} \mathrm{AI}$ calculated from 7 to $10.5 \mathrm{Myr}$ in Figures 7 and 8.

\subsection{Potential mineralization zones for model outputs}

Like the $P e$ and streamline distributions (Fig. 4), favourable $\mathrm{R}^{2}$ AIs were found around and/or above the pluton during the hottest phase. With exception of very shallow plutons, such as M1, no significant favourable mineral deposition zone is seen below the pluton floor. With increasing emplacement depth, the apical zone above the pluton remains the most favourable for mineralization, whilst the favourable zones located around pluton borders and corners decrease and disappear (Fig. 6). The models M1 and M2 show high-potential mineralization zones located along narrow discharge zones near the topographic surface. These result from second-order convection cells developing above the shallow plutons (see earlier). Figure 4 shows that these narrow advective zones produce thermal bulges where the fluids reach the surface at temperatures ranging from 150 to $100{ }^{\circ} \mathrm{C}$. We interpret these shallow focused 
mineralizing zones as low-temperature hydrothermal systems possibly responsible for the F$\mathrm{Ba}( \pm \mathrm{Pb}, \mathrm{Zn})$ mineralization characteristic of late-orogenic granite emplacement, or for the strong alteration leading to kaolinite deposits. For M3 and M4, the shallow high-potential deposition zones above the plutons appear unrealistic at first glance. This point will be discussed later.

\subsection{Effects of fractured aureoles}

Model M6, based on the Bruès intrusion-related gold deposit, is emplaced at $9.3 \mathrm{~km}$, i.e. intermediate between M3 and M4, whereas model M8, based on the Scheelite dome intrusionrelated gold deposit, is to be compared to M7. The most important difference between M6, M8 and the theoretical models is the presence of a fractured thermal aureole that acts as a high-permeability zone. These highly permeable zones $\left(10^{-15} \mathrm{~m}^{2}\right)$ were activated late during the magma emplacement, at $9.5 \mathrm{Myr}$, i.e. $5 \cdot 10^{5}$ years before the hottest phase.

The models show that highly permeable fractured aureoles are able to pump and focus the fluid flow and thus restrain and decrease the extent of the favourable zones (Fig. 7). In model M6, the upper corners of the pluton are one of the most probable mineralization sites during the hottest phase. This is in agreement with the location of the Bruès gold deposit at the upper north corner of the Boboras pluton (Fig. 1B). The focus and pumping of fluid into the permeable zone is also responsible for the good agreement between the Scheelite dome gold deposit and model M8 (Figs. 1C and 7). The development of a cracked thermal aureole around the stock induced the formation of a restricted and narrow probable mineralization zone along the borders of the stock (M8 in Fig. 7). Conversely to M6, the cracked thermal aureole of M8 is able to cancel out the large probable mineralization zone which developed from the pluton to the surface in M7 (M8 vs. M7, Figs. 6 and 7). This illustrates the largescale key role played by small-scale heterogeneous permeability structures in enhancing and depleting the potential for ore deposition.

\subsection{Effects of apexes}

At an emplacement depth of $8 \mathrm{~km}$, a short apex asserts a slight control over the $\mathrm{R}^{2} \mathrm{AI}$ distribution (M3 vs. M7 in Fig. 6); additional corners and inclined edges enable the probable mineralization zones to be closer to the pluton. A long apex, reaching into the shallow zone where the permeability is higher than $10^{-16} \mathrm{~m}^{2}$, relocates the positive $\mathrm{R}^{2} \mathrm{AI}$ zone around it 
(compare M3 in Fig. 6 and M10 in Fig. 8); the top of the apex acts as small shallow intrusion and plays a role in localizing a probable mineralization zone before the hottest phase of the magmatic system.

Comparisons with natural porphyries (e.g. the Grasberg $\mathrm{Cu}-\mathrm{Au}$ porphyry, Fig. 1C) are quite difficult because our models do not simulate the production of magmatic water and the ore is mostly hosted within the magmatic apex. However, the well-established alteration halos (Lowell and Guilbert, 1970) within Cu-porphyry host rocks may well correspond to the positive $\mathrm{R}^{2} \mathrm{AI}$ distribution shown in M10 (Fig. 8).

\subsection{Effects of faults}

Faults, in our models, were activated $\left(\mathrm{K}=10^{-15} \mathrm{~m}^{2}\right)$ for the entire duration of the experiment (i.e. $20 \mathrm{Myr}$ ). In model M10 (Fig. 8) the fault is mineralized from 8 to $10.5 \mathrm{Myr}$, although its presence does not drastically change the $\mathrm{R}^{2} \mathrm{AI}$ distribution around the apex, which appears to be the major control.

In model M11, the probable mineralization zone emerges at the hottest phase both within the fault and above the pluton (Fig. 8). After $5.10^{5} \mathrm{yr}$ of cooling, the favourable mineralization zone disappears (Fig. 8). At the hottest phase, the favourable zone above the pluton appears at the surface near the fault where the host-rock permeability is higher than that of the fault. The pluton roof in M11 is emplaced at $5 \mathrm{~km}$, i.e. between those of M2 and M3. Comparison between M2, M3 at the hottest phase (Fig. 6) on the one hand, and M11 (Fig. 8) on the other, shows that the flat-lying fault has a major effect on the fluid-flow patterns and resulting $\mathrm{R}^{2} \mathrm{AI}$ distribution. In fact the fault cancels the development of a potential mineralization zone around the pluton, prevents the development of second-order convection cells as in M2 (Figs. 4a and 6) and restrains the potential discharge near the surface. A very good agreement was found with the Crocetta deposit in Elba (Fig. 1D) where the Elba central detachment fault is a very efficient advective drain. Due to its low dip, this fault is able to pump and accelerate the fluids at depth and make them circulate along the horizontal branch of the pluton-induced convection cells. Detachments are thus able to delocalize and strongly modify classical fluid-flow patterns induced by coeval intrusion.

\subsection{Validity of the modelled mineralization patterns}

The calculated results only apply to situations in which mineral solubility depends on temperature with solubility decreasing with decreasing temperature. Qualitatively, in time and 
space, the chemistry of the ore-forming process affects application of our results in the following way. If the temperature dependence of mineral solubility is unusually low, ore deposition might not occur even in regions of elevated $\mathrm{TR}^{2} \mathrm{AI}$. Alternatively, if there are regions where the temperature dependence of mineral solubility is unusually high (such as near the fluid critical point, for example), then ore deposition may occur even in regions of low $\mathrm{TR}^{2} \mathrm{AI}$.

One other main point to be considered is the significance and reality of the near-surface favourable mineralization zone developed above the pluton at the hottest phase, which is particularly relevant for the intermediate plutons (e.g. M3, M4; Fig. 6). First, we approximated a homogenous crust with a power-law depth-dependent permeability variation (Equation 3), which is an approximation that does not take into account the potential permeability barriers encountered in many orogenic hydrothermal systems (e.g. Sibson et al., 1988). Secondly, the $\mathrm{R}^{2} \mathrm{AI}$ is a physical parameter that does not take into account solute transport and chemical reaction (see above). For these two reasons alone, great care has to be taken in any interpretation. We nevertheless think that the near-surface potential mineralization zone observed in our models is not totally unreasonable. Furthermore, it could well correspond to a system of geothermal hot springs associated with deep heat sources, or more generally to alteration zones where large amounts of hot fluids are efficiently cooled (Hall et al., 1974).

\subsection{Modelled pluton development vs. age of mineralization and genetic link}

Because of the inherent simplification in transient numerical modelling, short geological time spans can be difficult to access. This assumption is particularly valid for the Kucing Liar skarn (along the Indenberg fault) and the Grasberg $\mathrm{Cu}$-Au porphyry (Fig. 1C) which formed over a $4.10^{5}$ year time span. As an analogue, model M10 at 8 Myr (Fig. 8) shows that the Indenberg fault and the porphyry were both potential favourable zones before, during and after the hottest phase. The $\mathrm{TR}^{2} \mathrm{AI}$ applied to the porphyry system model (M10, Fig. 8b) shows an asymmetric distribution of maxima around the top of the apex, and located in between the fault and the apex. This suggests that the high-potential mineralization zones are restricted to the top of the apex, with the deeper zones remaining barren or low potential.

We also show that, leaving geochemical processes aside, a pure physical parameter such as $\mathrm{R}^{2} \mathrm{AI}$ applied to models of granite-related gold deposits (M6 and M8; Fig. 7) correctly reproduces the ore deposition relative to the pluton in both time and space. It would appear 
that intrusion-induced fluid convection is a key physical control to explain the spatial distribution of ore around the magmatic body. This is enhanced by cracked thermal aureoles developed around the intrusion (Fig. 7a). For granite-related gold deposits (M6, M8; Fig. 7b), time-integrated $\mathrm{R}^{2} \mathrm{AI}$ maxima correspond to the pluton corners and inclined flanks of the apex. These time-integrated favourable mineralization patterns are very close to those obtained at the hottest phase, which argues strongly for the key thermal role played by the intruded magmas in this type of gold deposit. This is also consistent with the short time lag of 2 Myr spanning the granite emplacement and the mineralization events at the Scheelite dome (see earlier).

As emphasized in the introduction, fluid-inclusion studies do not provide strong chemical arguments for a genetic link between granite and mineralization. Based on this lack of chemical evidence (e.g. no brines in fluid inclusions), granite is commonly only interpreted as a rheological and structural trap with no direct genetic relationship with the associated ore deposition; and this despite the radiometric time span between granite crystallization and mineralization being less than 2 Myr. Our models show that, from a physical point of view, hydrothermal convection created by magma emplacement is able to develop probable mineralization zones. The role of the intrusion is then clearly genetic for this kind of deepseated granite-related Au deposit, with mineral deposition possibly being almost coeval with the hottest phase of intrusion.

Finally, the $\mathrm{TR}^{2} \mathrm{AI}$ distribution applied to the detachment system (M11; Fig. 8b) shows very restrained maxima near the surface and within the fault. This time-integrated pattern is fully acquired precisely at the hottest phase. Therefore, as with granite-related gold deposits, our models argue for a strong genetic link between the La Crocetta raw-material deposits and the Monte Capanne pluton emplacement beneath the Ebla detachment.

\section{Concluding remarks:}

Our models are simple physical models that simulate neither multiphase fluids, chemical diffusion, topography, nor production of magmatic waters. Nevertheless, the originality of our modelling relative to earlier work is that: i) we applied a continuous variation of crust permeability with depth; ii) the models are transient and account for the emplacement period of the intrusion; iii) we tested for the physical favourability of ore deposition; iv) we compared our models with well-constrained natural examples at different emplacement depths 
and with the contribution of high permeability zones such as cracked thermal aureoles and faults; and v) we explored the pluton floor zone.

Our main results are that:

1. Fluid-circulation and mineralization patterns are strongly dependent on the emplacement depth of the pluton. Deep-seated plutons emplaced below $10 \mathrm{~km}$ (permeability threshold of $7.10^{-18} \mathrm{~m}^{2}$ ) and not connected to high-permeability zones do not induce advective heat dissipation. If the pluton emplacement is above $4.5 \mathrm{~km}$, then a permeability threshold of $10^{-16} \mathrm{~m}^{2}$ is reached and second-order convection cells may create additional focused discharge zones where mineralization can be expected.

2. With the exception of very shallow plutons, the pluton floor zone is not favourable for mineral deposition.

3. Pluton apexes strongly modify the fluid-flow pattern by focusing convective fluids and mineralization zones around them. In mineralized porphyry systems, the focusing of convective fluids around the top of the magmatic stock might possibly be favourably combined with the production of magmatic water to trigger ore formation.

4. The cooling phase is not the main convection phase for large plutons associated with long-lived magma emplacement. Major advective heat dissipation and mineraldeposition zones may also develop some time before and during the hottest phase of emplacement, before the magma cools. This is an important clue for interpreting absolute dating results (intrusion emplacement and cooling ages) obtained on intrusion-related ore deposits.

5. Detachment faults are able to delocalize and strongly modify classical fluid-flow patterns induced by a coeval intrusion. Extensional systems do not require lithostatic fluid overpressure to develop dilatant sites likely to drain and/or trap mineralization. This result implies that it is surprising that very few giant ore deposits are recognized in a context of detachment faults associated with metamorphic core complexes.

6. Favourable physical conditions for mineral deposition develop around mid-crust plutons over a short time span bracketing the hottest phase of intrusion. We conclude that, even though chemical processes are absent from our models, fluid convections induced by granite emplacement (involving fast local cooling rates) plays a key role in the genesis of granite-related $\mathrm{Au}$ deposits. Moreover, the formation of this type of deposit is favoured and controlled by the presence of a fractured thermal aureole around the intrusion. 


\section{References}

Annen, C., Scaillet, B., Sparks, S.J., 2006. Thermal constraints on the emplacement rate of a large intrusive complex: the Manaslu Leucogranite, Nepal Himalaya. J. Petrol. 47, 7195.

Arndt, N.T., Lesher, C.M., Czamanske, G.K., 2005. Mantle-derived magmas and magmatic $\mathrm{Ni}-\mathrm{Cu}-$ (PGE) deposits. Econ. Geol. 100th Anniversary Volume, 5-24.

Baker, T., Lang, J.R., 2001. Fluid inclusion characteristics of intrusion-related gold mineralization, Tombstone-Tungsten magmatic belt, Yukon Territory, Canada. Mineral. Deposita. 36, 563-582.

Bouillin, J.P., Bouchez, J.L., Lespinasse, P., Pêcher, A., 1993. Granite emplacement in an extensional setting: an AMS study of the magmatic structures of Monte Capanne (Elba, Italy). Earth Planet. Sci. Lett. 118, 263-279.

Carr, P.M., Cathles, L.M., Barrie, C.T., 2008. On the size and spacing of volcanogenic massive sulfide deposits within a district with application to the Matagami district, Quebec. Econ. Geol. 103, 1395-1409.

Cathles, L.M., 1977. An analysis of cooling of intrusives by ground-water convection which includes boiling. Econ. Geol. 72, 804-826.

Cathles, L.M., 1981, Fluid flow and genesis of hydrothermal ore deposits. Econ. Geol. 75, 424-457.

Cerny, P., Blevin, P.L., Cuney, M., London, D., 2005. Granite-related ore deposits, in: Hedenquist, J.W., Thompson, J.F.H, Goldfarb, R.J., Richards, J.P. (Eds), One hundredth Anniversary Volume 1905-2005. Society of Economic Geologists. 100th Anniversary. 337-370.

Clauser, C., 2003. Numerical Simulation of Reactive Flow in Hot Aquifers-SHEMAT and Processing SHEMAT, Springer Publishers, Heidelberg.

Clauser, C., 2006. Geothermal energy, in: Heinloth, K. (ed.) Landolt-Börnstein, Group VIII: Advanced material and technologies, Vol. 3: Energy Technologies, Subvol C: Renewable Energies, Springer Verlag, Heidelberg-Berlin, pp. 493-604.

Clemens, J.D., Mawer, C.K., 1992. Granitic magma transport by fracture propagation. Tectonophysics. 204, 339-360. 
Cook, S.J., Bowman, J.R., Forster, G.B., 1997. Contact metamorphism surrounding the Alta stock: finite element model simulation of heat- and ${ }^{18} \mathrm{O} /{ }^{16} \mathrm{O}$ mass-transport during prograde metamorphism. Am. J. Sci. 297, 1-55.

Coumou, D., Driesner, T., Geiger, S., Heinrich, C.A., Matthaï, S., 2006. The dynamics of mid-ocean ridge hydrothermal systems: starting plumes and fluctuating vent temperatures, Earth Planet. Sci. Lett. 245, 218-231.

Cui, X., Nabelek, P.I., Liu, M., 2001. Controls of layered and transient permeability on fluid flow and thermal structure in contact metamorphic aureoles, with application to the Notch Peak aureole, Utah. J. Geophys. Res. 106, 6477-6491.

De Launay, L., 1913. Traité de Minéralogie. Gîtes minéraux et métallifères. Beranger, Paris.

Dipple, G.M., Ferry, J.M., 1996. The effect of thermal history on the development of mineral assemblages during infiltration-driven contact metamorphism. Contrib. Mineral. Petrol. 124, 334-345.

Driesner, T., Geiger, S., 2007. Numerical simulation of multiphase fluid flow in hydrothermal systems. Rev. Mineral. Geochem. 65, 187-212.

Ferry, J.M., Dipple, G.M., 1992. Models for coupled fluid flow, mineral reaction, and isotopic alteration during contact metamorphism: The Nitch Peak aureole, Utah. Am. Mineral. 77, 577-591.

Ferry, J.M., Sorensen, S.S., Rumble, D., 1998. Structurally controlled fluid flow during contact metamorphism in the Ritter Range pendant. California, USA. Contrib. Mineral. Petrol. 130, 358-378.

Ferry, J.M., Wing, B., Penniston-Dorland, S., Rumble, D., 2002. The direction of fluid flow during contact metamorphism of siliceous carbonate rocks: new data for the Monzoni and Predazzo aureoles, northern Italy, and a global review. Contrib. Mineral. Petrol. 142, 679-699.

Fontaine, F.J., Rabinowicz, M., Boulègue, J., 2001. Permeability changes due to mineral diagenesis in fractured crust: implications for hydrothermal circulation at mid-ocean ridges, Earth Planet. Sci. Lett., 184, 407-425.

Gerdes, M.L., Baumgartner, L.P., Person, M. 1998. Convective fluid flow through heterogeneous country rocks during contact metamorphism. J. Geophys. Res. 103, $23,983-24,003$.

Gloaguen, E., Chauvet, A., Branquet, Y., Gerbeaud, O., Ramboz, C., Bouchot, V., Lerouge, C., Monié, P., Cathelineau, M., Boiron M.C., Marignac, C., Pourraz, N., Fourcade, S., 
Ruffet, G., Iglesias Ponce de León, M., 2003. Relations between Au/Sn-W mineralizations and late Hercynian granite: preliminary results from the Schistose Domain of Galicia-Trás-os-Montes Zone, Spain, in: Eliopoulos D. et al. (eds), 7th biennal SGA meeting - Mineral Exploration and Sustainable Development, Athens, Greece, 271-274.

Gloaguen, E., 2006. Apports d'une étude intégrée sur les relations entre granites et minéralisations filoniennes ( $\mathrm{Au}$ et $\mathrm{Sn}-\mathrm{W}$ ) en contexte tardi-orogénique (Chaîne Hercynienne, Galice Centrale, Espagne), Ph.D. Thesis, Orléans University, France, http://tel.archives-ouvertes.fr/, 571p.

Gow, P.A., Upton, P., Zhao, C., Hill, K.C., 2002. Copper-gold mineralisation in New Guinea: numerical modelling of collision, fluid flow and intrusion-related hydrothermal systems. Austral. J. Earth Sci. 49, 753-771.

Hall, W.E., Friedman, I., Nash, J.T., 1974. Fluid inclusion and light stable isotope study of Climax molybdenum deposits, Colorado. Econ. Geol. 69, 884-901.

Hanson, R.B., 1992. Effects of fluid production on fluid flow during regional and contact metamorphism. J. Metam. Geol. 10, 87-97.

Hanson, R.B., 1995. The hydrodynamics of contact metamorphism. GSA Bull. 107, 595-611.

Harcouët, V., 2005. Modélisations thermiques de gisements orogéniques mésothermaux: application au Ghana, Ph.D. Thesis, Institut de Physique du Globe de Paris, France, http://tel.archives-ouvertes.fr/, $266 \mathrm{p}$.

Harcouët-Menou, V., Guillou-Frottier, L., Bonneville, A., Adler, P.M., Mourzenko, V., 2009. Hydrothermal convection in and around mineralized fault zones: insights from twoand three-dimensional numerical modelling applied to the Ashanti belt, Ghana. Geofluids, 9, 116-137.

Hayba, D.O., Ingebritsen, S.E., 1997. Multiphase groundwaterflow near cooling plutons. J. Geophys. Res. 102, 12235-12252.

Ingebritsen, S.E., Manning, C.E., 1999. Geological implication of a permeability-depth curve for the continental crust. Geology. 27, 1107-1110.

Kestin, J., Khalifa, H.E., Abe, Y., Grimes, C.E., Sookiazan, H., Wakehan, W.A., 1978. Effect of the pressure on the viscosity of aqueous $\mathrm{NaCl}$ solutions in the temperature range 20-150 ${ }^{\circ}$ C. J. Chem. Eng. Data, 23, 328-336.

Kipp, K.L., Jr., Hsieh, P.A., Charlton, S.R., 2008. Guide to the revised ground-water flow and heat transport simulator: HYDROTHERM - Version 3: U.S. Geological Survey Techniques and Methods 6-A25, $160 \mathrm{p}$. 
Kühn, M., Dobert, F., Gessner, K., 2006. Numerical investigation of the effect of heterogeneous permeability distributions on free convection in the hydrothermal system at Mount Isa, Australia. Earth Planet. Sci. Lett. 244, 655-671.

Lang, J.R., Baker, T., 2001. Intrusion-related gold systems: the present level of understanding. Mineral. Deposita. 36, 477-489.

Lowell, J.D., Guilbert, J.M., 1970. Lateral and vertical alteration - mineralization zoning in porphyry ore deposits. Econ. Geol. 65, 373-408.

Maineri, C., Benvenuti, M., Costagliola, P., Dini, A., Lattanzi, P., Ruggieri, G., Villa, I.M., 2003. Sericitic alteration at the La Crocetta deposit (Elba Island, Italy): interplay between magmatism, tectonics and hydrothermal activity. Mineral. Deposita. 38, 6786.

Mair, J.L., Goldfarb, R.J., Johnson, C.A., Hart, C.J.R., Marsh, E.E., 2006. Geochemical Constraints on the Genesis of the Scheelite Dome Intrusion-Related Gold Deposit, Tombstone Gold Belt, Yukon, Canada. Econ. Geol. 101, 523-553.

Manning, C.E., Ingebritsen, S.E., 1999. Permeability of the continental crust: implications of geothermal data and metamorphic systems. Rev. Geophys. 37, 127-150.

Michaut, C., Jaupart, C., 2006. Ultra-rapid formation of large volumes of evolved magma. Earth Planet. Sci. Lett. 250, 38-52.

Nabelek, P.I., Labotka, T.C., 1993. Implications of geochemical fronts in the Notch Peak contact-metamorphic aureole, Utah, USA. Earth Planet. Sci. Lett. 119, 539.

Norton, D., Knapp, R., 1977. Transport phenomena in hydrothermal systems: the nature of porosity. Am. J. Sci. 277, 913-936

Norton, D., Knight, J., 1977. Transport phenomena in hydrothermal systems: cooling plutons. Am. J. Sci. 277, 937-981.

Oliver, N.H.S., McLellan, J.G., Hobbs, B.E., Cleverley, J.S., Ord, A., Feltrin, L., 2006. Numerical models of extensional deformation, heat transfer, and fluid flow across basement-cover interfaces during basin-related mineralization. Econ. Geol. 101, 1-31.

Petford, N., Cruden, A.R., McCaffrey, K.J.W., Vigneresse, J-L., 2000. Granitic magma formation, transport and emplacement in the Earth's crust. Nature. 408, 669-673.

Phillips, O.M., 1991. Flow and reactions in permeable rocks. Cambridge University Press, Cambridge. $285 \mathrm{p}$.

Pollard, P.J., Taylor, R.G., Peters, L., 2005. Ages of intrusion, alteration, and mineralization at the Grasberg Cu-Au deposit, Papua, Indonesia. Econ. Geol. 100, 1005-1020. 
Rabinowicz, M., Boulègue, J., Genthon, P., 1998. Two and three-dimensional modelling of hydrothermal convection in the sedimented Middle Valley segment, Juan de Fuca Ridge. J. Geophys. Res. 103, 24045-24065.

Raffensperger, J.P., Vlassopoloulos, D., 1999. The potential for free and mixed convection in sedimentary basins, Hydrogeol. J. 7, 505-520.

Rossetti, F., Tecce, F., Billi, A., Brilli, M., 2007. Patterns of fluid flow in the contact aureole of the Late Miocene Monte Capanne pluton (Elba Island, Italy): the role of structures and rheology. Contrib. Mineral. Petrol. 153, 743-760.

Seedorf, E., Dilles, J.H., Proffett, J.M.J., Einaudi, M.R., Zurcher, L., Stavast, W.J.A., Johnson, D.A., Barton, M.D., 2005. Porphyry copper deposits: Characteristics and origin of hypogene features. Econ. Geol., 100th Anniversary Volume, 251-298.

Sibson, R.H., Robert, F., Poulsen, H.H.A.F., 1988. High angle faults, fluid pressure cycling, and mesothermal gold-quartz deposits. Geology 16, 551-555.

Sillitoe, R.H., 1991. Intrusion-related gold deposits, in: Foster, R.P. (ed), Gold metallogeny and exploration. Blackie, Glasgow, 165-209.

Stephens, J.R., Mair, J.L., Oliver, N.H.S., Hart, C.J.R., Baker, T., 2004. Structural and mechanical controls on intrusion-related deposits of the Tombstone Gold Belt, Yukon, Canada, with comparisons to other vein-hosted ore-deposit types. J. Struct. Geol. 26, 1025-1041.

Stern, L.A., Chamberlain, C.P., Barnett, D.E., Ferry, J.M., 1992. Stable isotope evidence for regional-scale fluid migration in a Barrovian metamorphic terrane, Vermont, USA. Contrib. Mineral. Petrol. 112, 475-489

Thompson, J.F.H., Sillitoe, R.H., Baker, T., Lang, J.R., Mortensen, J.K., 1999. Intrusionrelated gold deposits associated with tungsten-tin provinces. Mineral. Deposita. 34, 323-334.

Thompson, J.F.H., Newberry, R.J., 2000, Gold deposits related to reduce granitic intrusions, in: Hagemann, S.G., Brown, P.E. (Eds), Gold in 2000. Reviews in Economic Geology. Society of Economic Geologists, Littleton, CO, USA, pp 377-400.

Wilcock, W.S.D., 1998. Cellular convection models of mid-ocean ridge hydrothermal circulation and the temperatures of black smoker fluids. J. Geophys. Res., 103, 25852596. 
Wing, B.A., Ferry, J.M., 2002. Three-dimensional geometry of metamorphic fluid flow during Barrovian regional metamorphism from an inversion of combined petrologic and stable isotopic data. Geology. 30, 639-642.

Wood, R., Hewett, T., 1982. Fluid convection and mass transfer in porous limestones: a theoretical model. Geochem. Cosmochim. Acta 46, 1707-1713.

Xu, T., Sonnenthal, E.L., Spycher, N., Pruess, K., 2004. TOUGHREACT user's guide: a simulation program for non-isothermal multiphase reactive geochemical transport in variable saturated geologic media, Lawrence Berkeley National Laboratory Report LBNL-55460, Berkeley, California.

Zhao, C., Hobbs, B.E., Mühlhaus, H.B., 1998. Finite element modelling of temperature gradient driven rock alteration and mineralization in porous rock masses. Comput. Meth. Appl. Mech. Eng. 165, 175-187.

Zhao, C., Hobbs, B.E., Walshe, J.L., Mühlhaus, H.B., Ord, A., 2001. Finite element modelling of fluid-rock interaction problems in pore-fluid saturated hydrothermal/sedimentary basins. Comput. Meth. Appl. Mech. Eng. 190, 2277-2293.

Zhao, C., Lin, G., Hobbs, B.E., Ord, A., Wang, Y., Mühlhaus, H. B. 2003. Effects of hot intrusions on pore fluid flow and heat transfer in fluid-saturated rocks, Comput. Meth. Appl. Mech. Eng. 192, 2007-2030. 
Table 1: Units and symbols of the parameters and variables used in this study. The thermal conductivity and specific heat capacity of the fluid, the host rock and the intruded body are temperature-dependent with respective ambient temperature values equal to $0.6 \mathrm{~W} \cdot \mathrm{m}^{-1} \cdot \mathrm{K}^{-1}$ and $4200 \mathrm{~J} \cdot \mathrm{kg}^{-1} \cdot \mathrm{K}^{-1}$ for the fluid, $3 \mathrm{~W} \cdot \mathrm{m}^{-1} \cdot \mathrm{K}^{-1}$ and $880 \mathrm{~J} \cdot \mathrm{kg}^{-1} \cdot \mathrm{K}^{-1}$ for the host rock, and $2.5 \mathrm{~W} \cdot \mathrm{m}^{-}$ ${ }^{1} \cdot \mathrm{K}^{-1}$ and $790 \mathrm{~J} \cdot \mathrm{kg}^{-1} \cdot \mathrm{K}^{-1}$ for the intruded body. 


\section{Figure Captions}

Figure 1: Compilation of the geometry, emplacement depth (ED) and geological context for different tested case studies (see text for geology and details). A: Emplacement depth of models M1 to M5 along the depth-permeability curve used in this study (modified from Manning and Ingebritsen, 1999). All intrusions are $10 \mathrm{~km}$ wide and $2.5 \mathrm{~km}$ thick (see Fig. 2). The permeability threshold of free convection $\left(10^{-16} \mathrm{~m}^{2}\right)$ established from the literature is shown in very pale grey. B: Synthetic sketch of the Boborás pluton and associated Bruès gold deposit, Hercynian belt, Galicia, Spain (model M6). C: Natural examples of intrusion-related ore deposits associated with plutonic apexes. ED and dimensions $(10 \mathrm{~km} \times 2.5 \mathrm{~km})$ of the main plutonic body (i.e. the upper crustal batholith) are realistic approximations. Models M7 and M8 are based on the Scheelite dome gold deposit; the ED of the stock roof and mineralization (i.e. $7 \mathrm{~km}$ ) is shallower than M6. M8 includes a fractured aureole, absent in M7. Models M9 and M10 represent typical cases of a porphyry-type mineralization; the selected example is the famous Grasberg $\mathrm{Cu}$-Au porphyry in the Irian-Jaya fold and thrust belt. Different hypothesis were tested: M9 without faults, M10 with faults. D: Geometries and structures of the Monte Capanne pluton and La Crocetta raw-material deposit along the Elba central detachment used for modelling fluid flow around plutons emplaced during low-angle extensional faulting (M11).

Figure 2: Simplified forms and boundary conditions for the different models; M1 to M5 represent theoretical models with different emplacement depths, and M6 to M11 represent models of tested natural cases, ED: emplacement depth of the intrusion roof. See text for detailed comments.

Figure 3: Benchmark test of our transient coupled hydro-thermal modelling. Model M1 of Gerdes et al., (1998) at time $10^{5}$ years is shown in the middle, whilst the bottom figure, with a fixed heat flux condition at the base, reproduces both the thermal and fluid-velocity patterns, as well as the velocity values.

Figure 4: Hydrodynamics and illustration of local Peclet number $(P e)$ values in different models at different time periods. The coloured areas show the advective zones $(P e>1)$ around 
each pluton $(P e=1$ in blue, with increasing values from blue through green and yellow to red); the $P e$ maximum is indicated. The streamlines are in black and labelled isotherms in red. Maximal and minimal fluid-velocity values for the bulk model are also indicated.

Figure 5: Horizontal component of the fluid velocity along horizontal cross-sections above the pluton at the hottest phase of intrusion (i.e. $10 \mathrm{Myr}$; see location of the cross-section on Fig. 2). Each fluid-velocity high and low along the $\mathrm{x}$ axis represents a convective cell. The shallowest plutons (M1, M2) show four convective cells while no significant variation was noted for the deepest pluton M5.

Figure 6: Application of $\mathrm{R}^{2} \mathrm{AI}$ around plutons with different depths of emplacement at the hottest phase of intrusion (i.e. $10 \mathrm{Myr}$ ). Grey areas are favourable zones of mineral deposition corresponding to $\mathrm{R}^{2} \mathrm{AI}=1$.

Figure 7: a) Focused snapshots during the warming and the cooling phases of plutons (hottest phase at $10 \mathrm{Myr}$ ) associated with a fractured thermal aureole (M6) and with the aureole and an apex (M8). These are simplified numerical models of the Bruès and Scheelite dome granite-related gold deposits, respectively (see Fig. 1 for the geological context). Grey areas are favourable zones of mineral deposition corresponding to $\mathrm{R}^{2} \mathrm{AI}=1$. b) Time-integrated $\mathrm{R}^{2} \mathrm{AI}\left(\mathrm{TR}^{2} \mathrm{AI}\right)$ from 7 to $10.5 \mathrm{Myr}$ for M6 and M8.

Figure 8: a) Same as Figure 7 for plutons with a high-angle dip fault (M10) and with an associated detachment fault (M11). These are simplified numerical models of the Grasberg porphyry and the Crocetta raw-material deposits above the Elba detachment, respectively (see Fig. 1 for the geological context). b) Time-integrated $\mathrm{R}^{2} \mathrm{AI}\left(\mathrm{TR}^{2} \mathrm{AI}\right)$ from 7 to $10.5 \mathrm{Myr}$ for M10 and M11. 

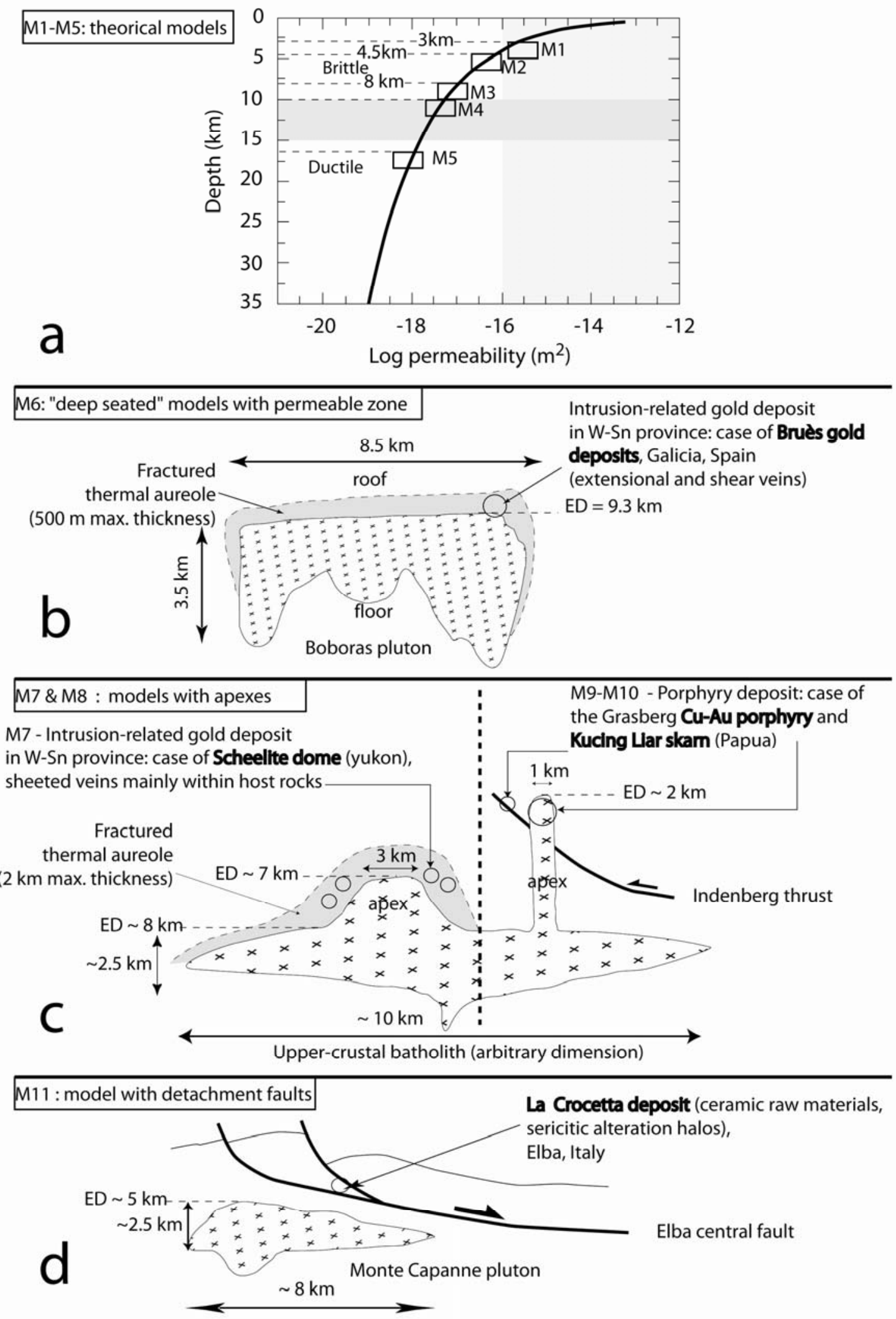


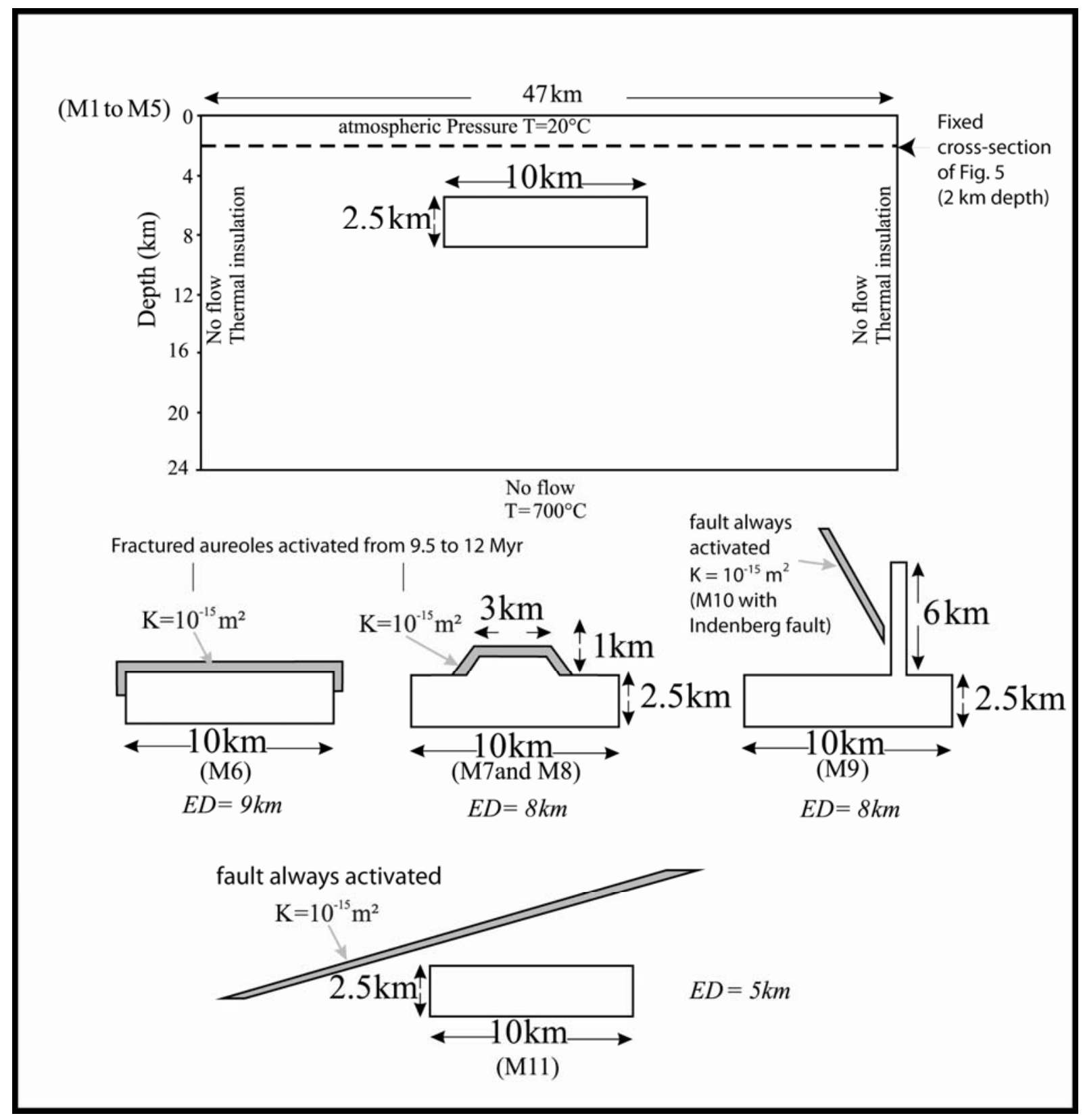




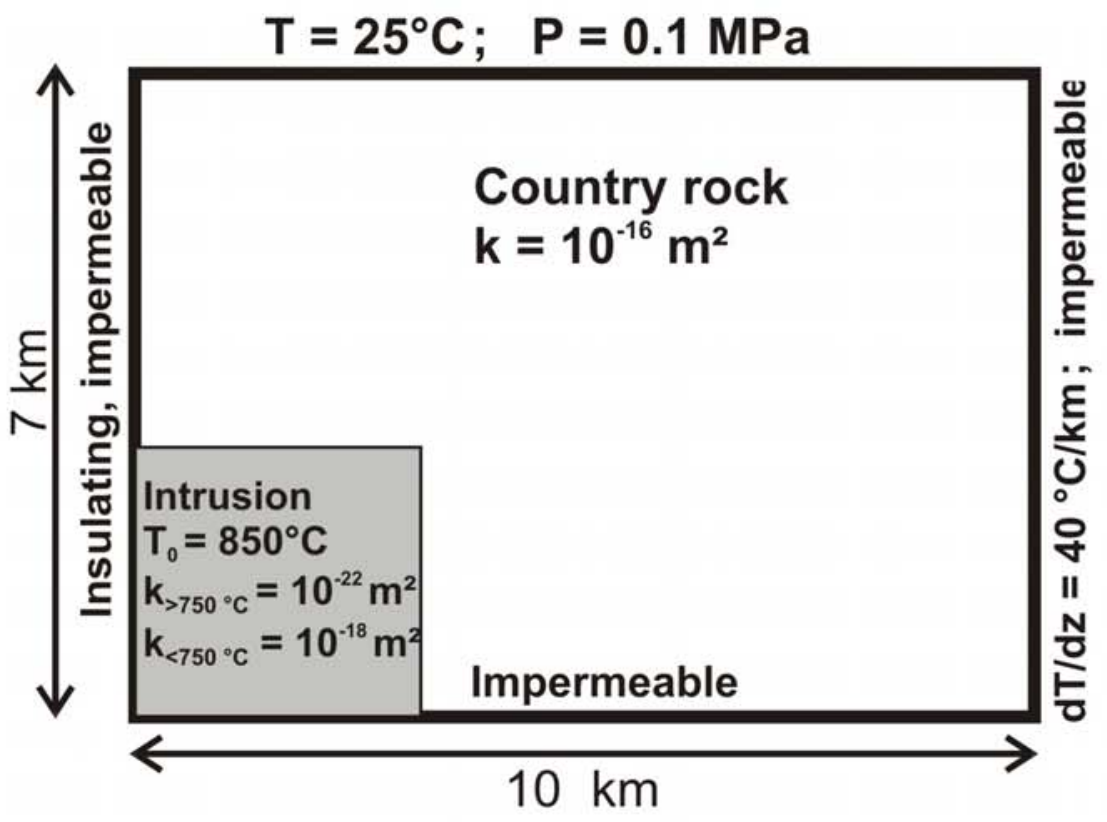

Gerdes et al. (1998) - Model M1, time $=10^{5} \mathrm{yr}$.

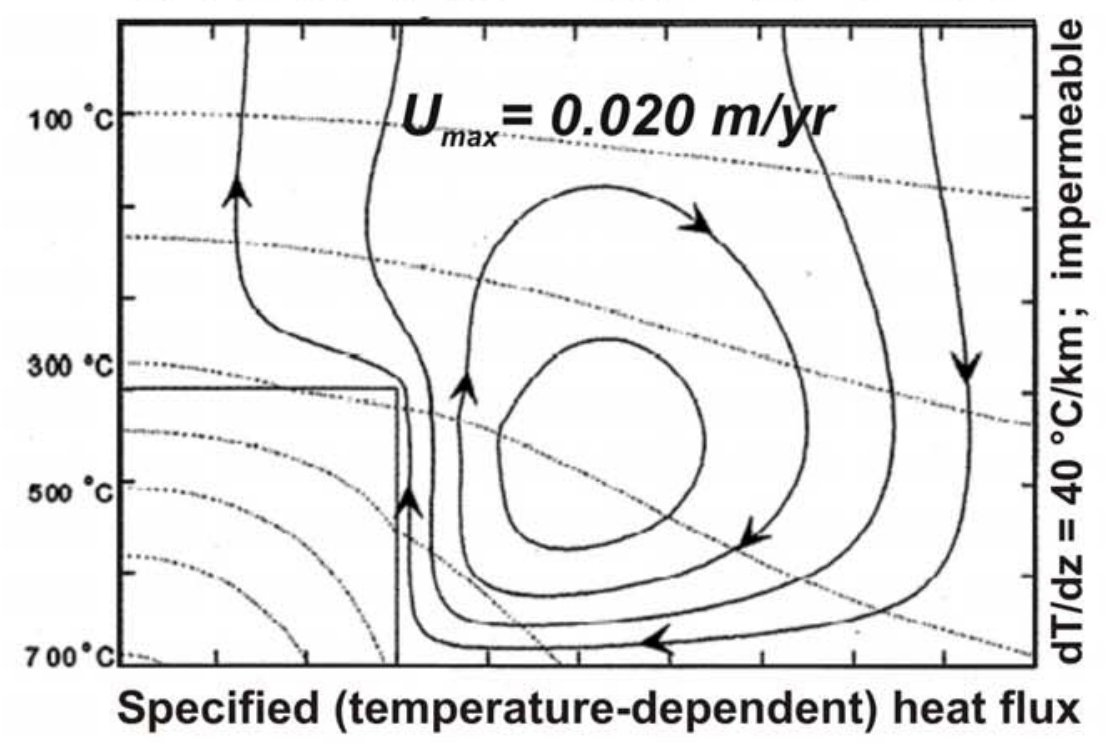

This study, time $=10^{5} \mathrm{yr}$.

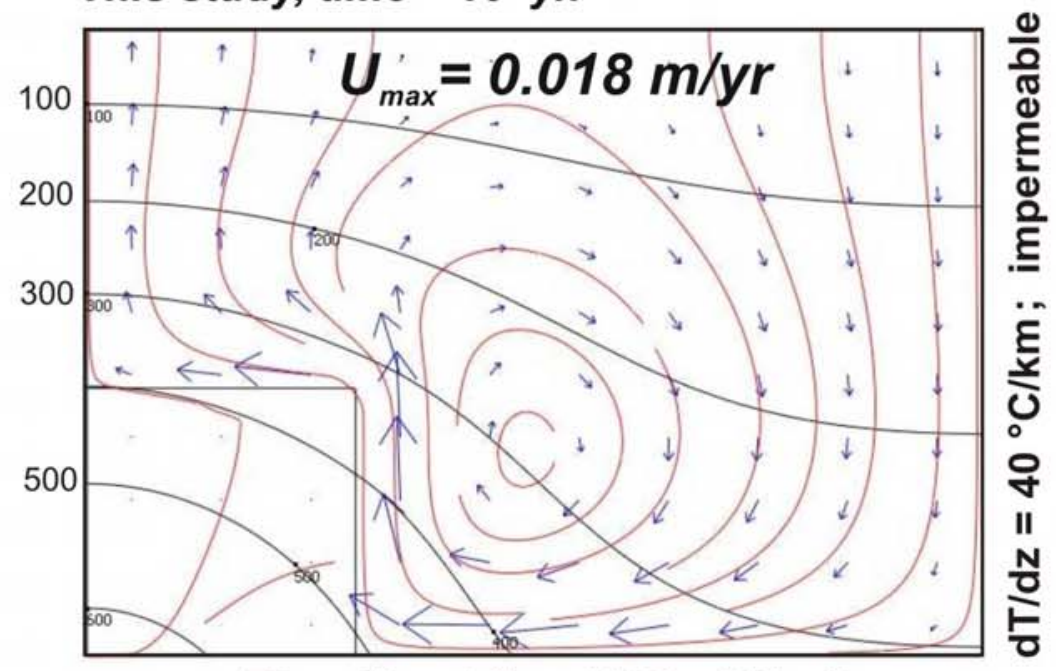

Fixed heat flux $\left(120 \mathrm{~mW} / \mathrm{m}^{2}\right)$ 


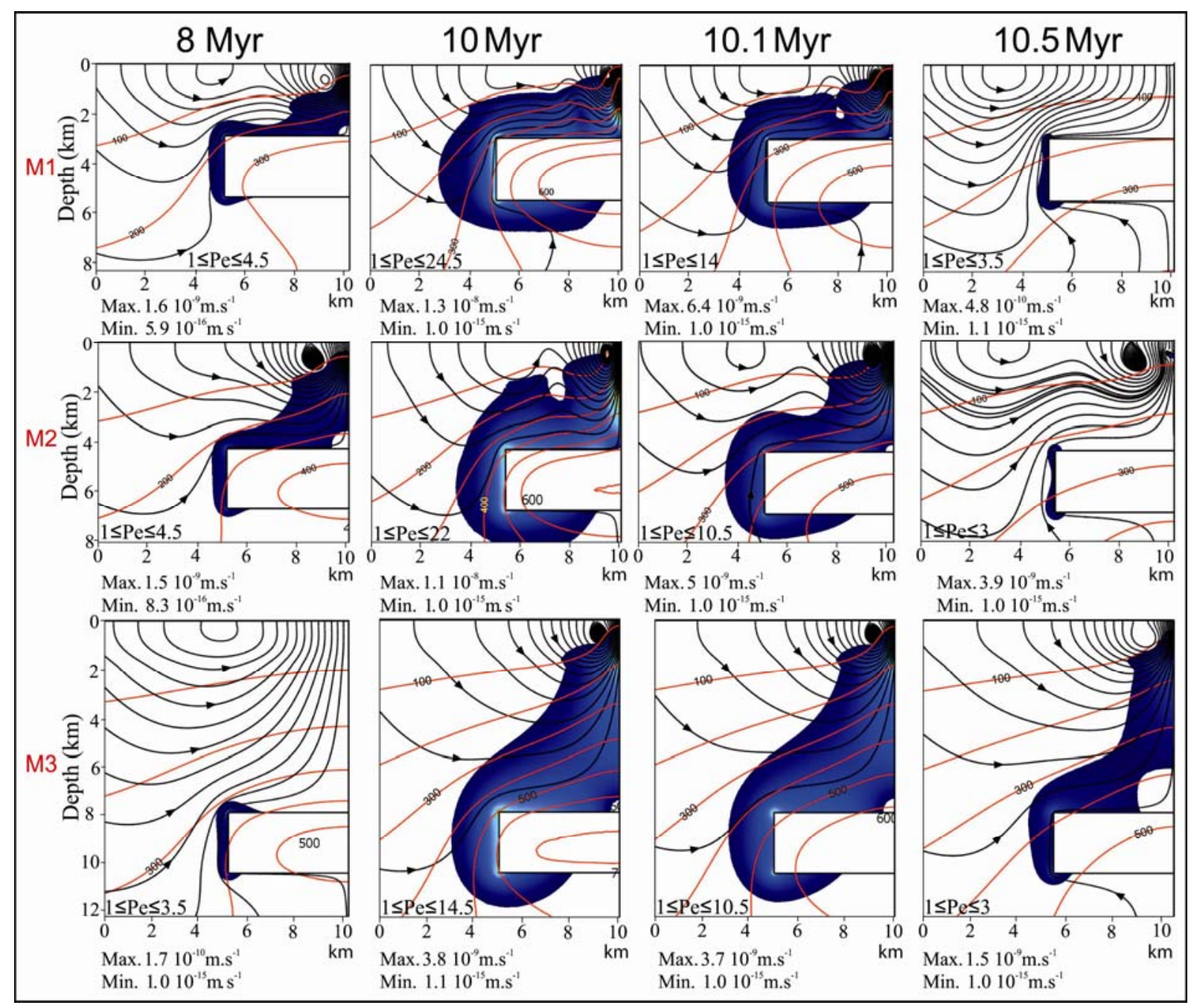




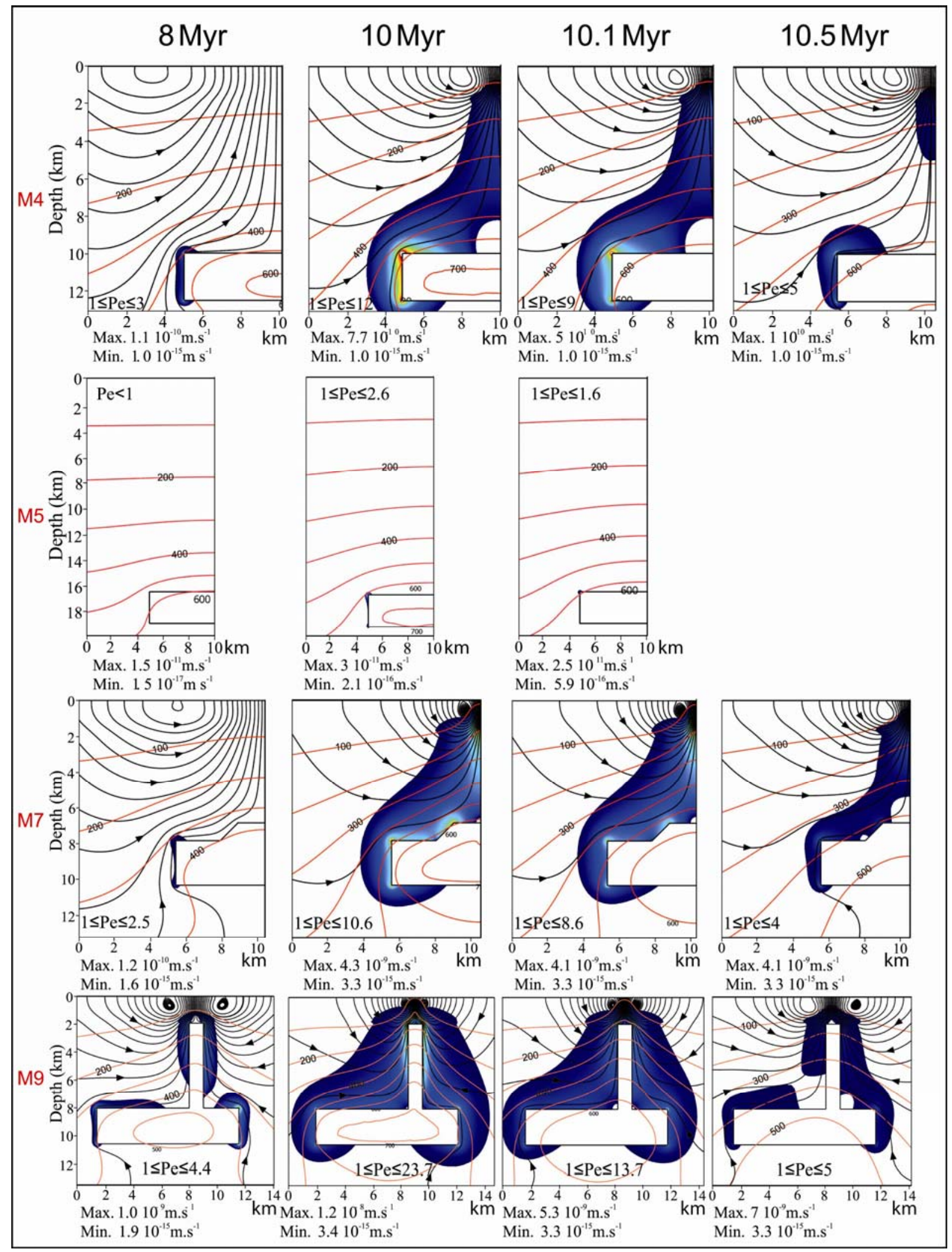




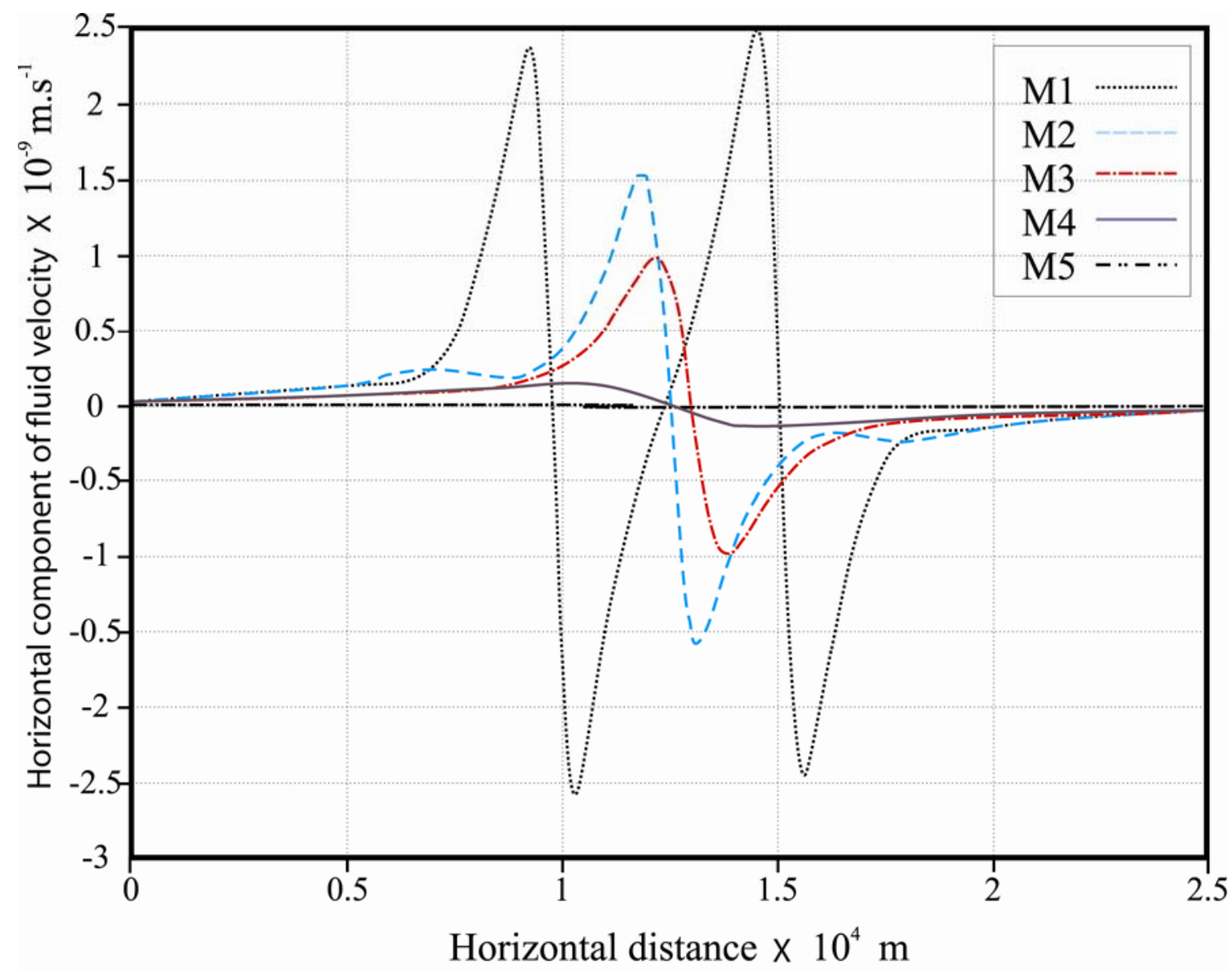



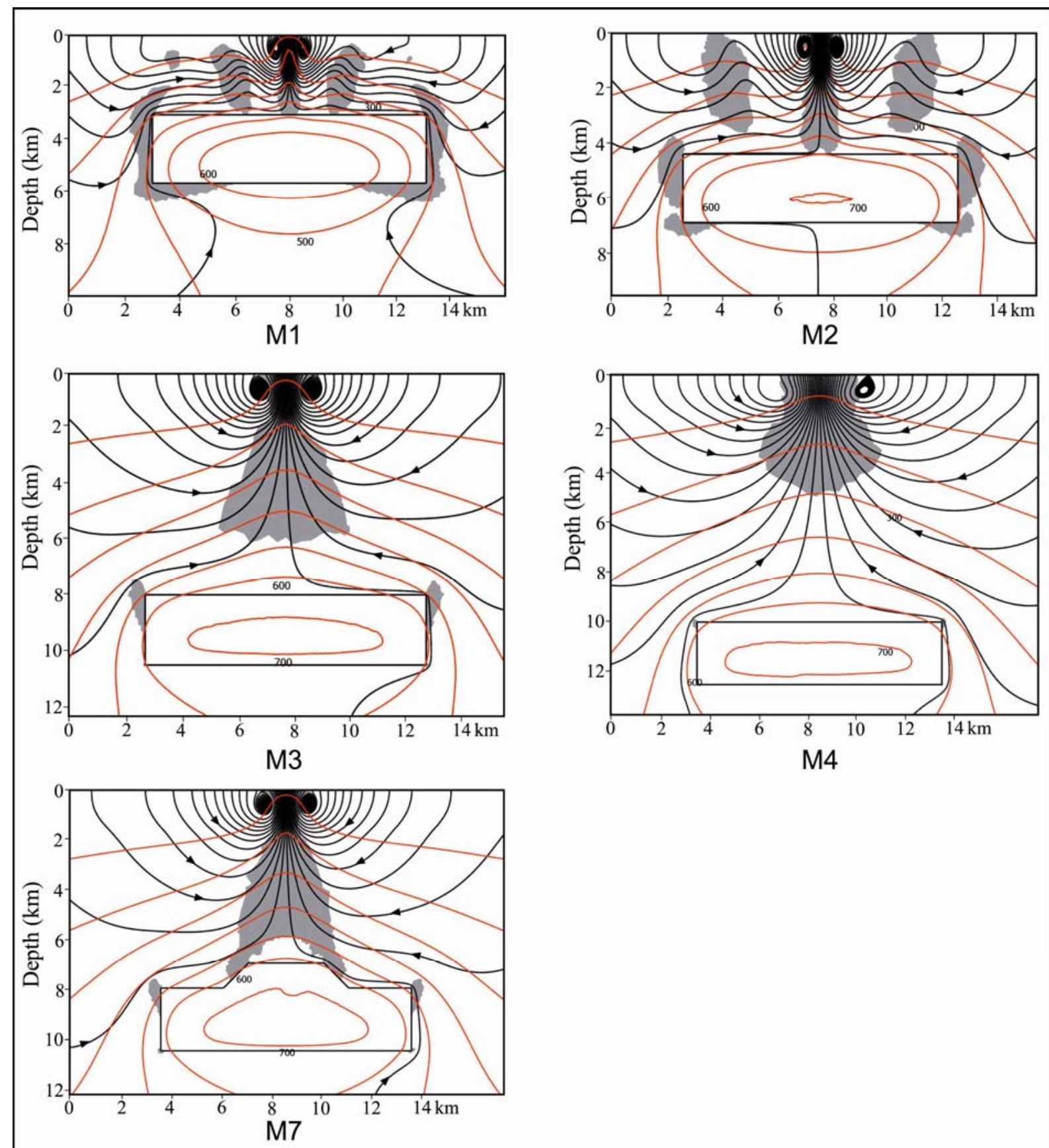

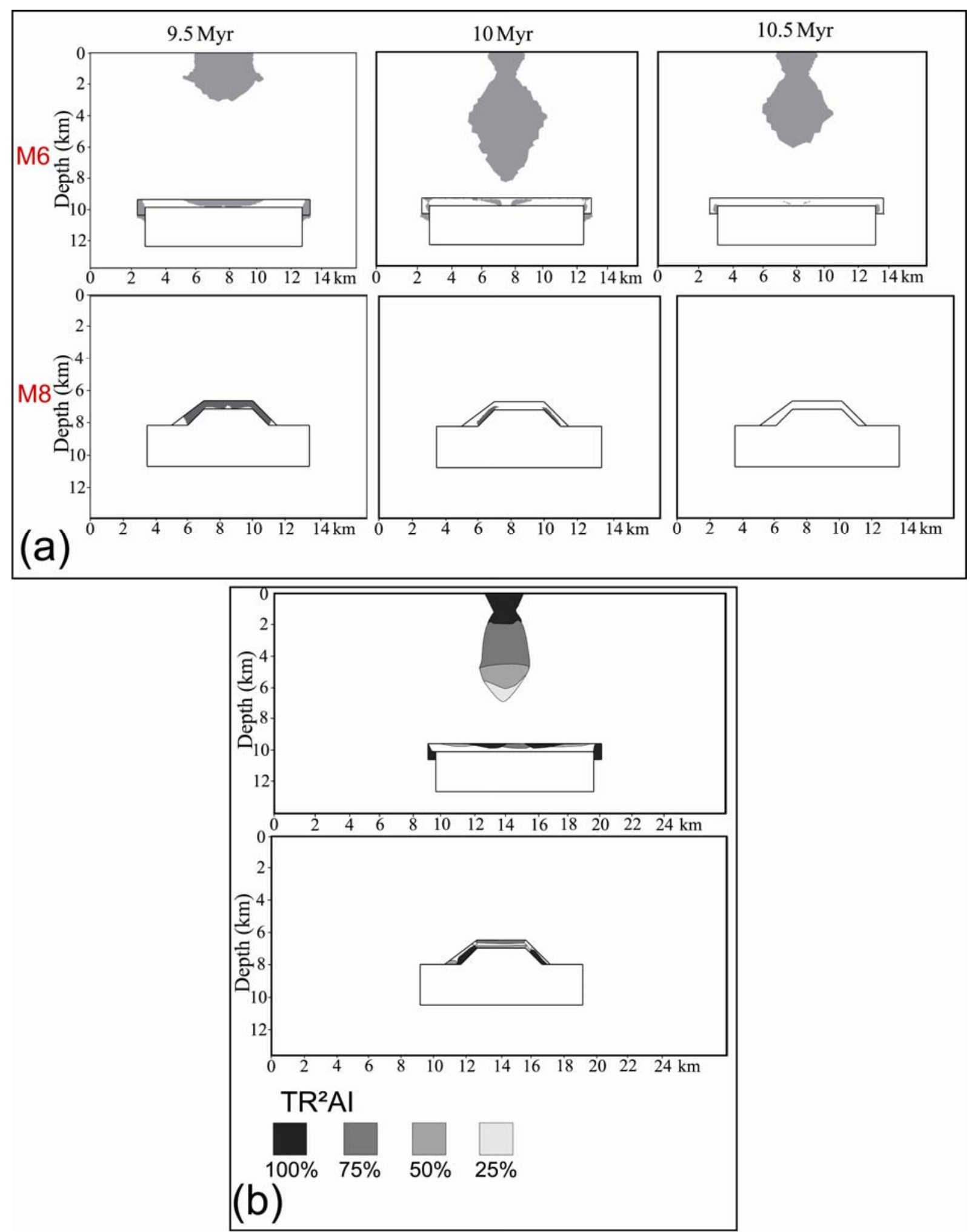


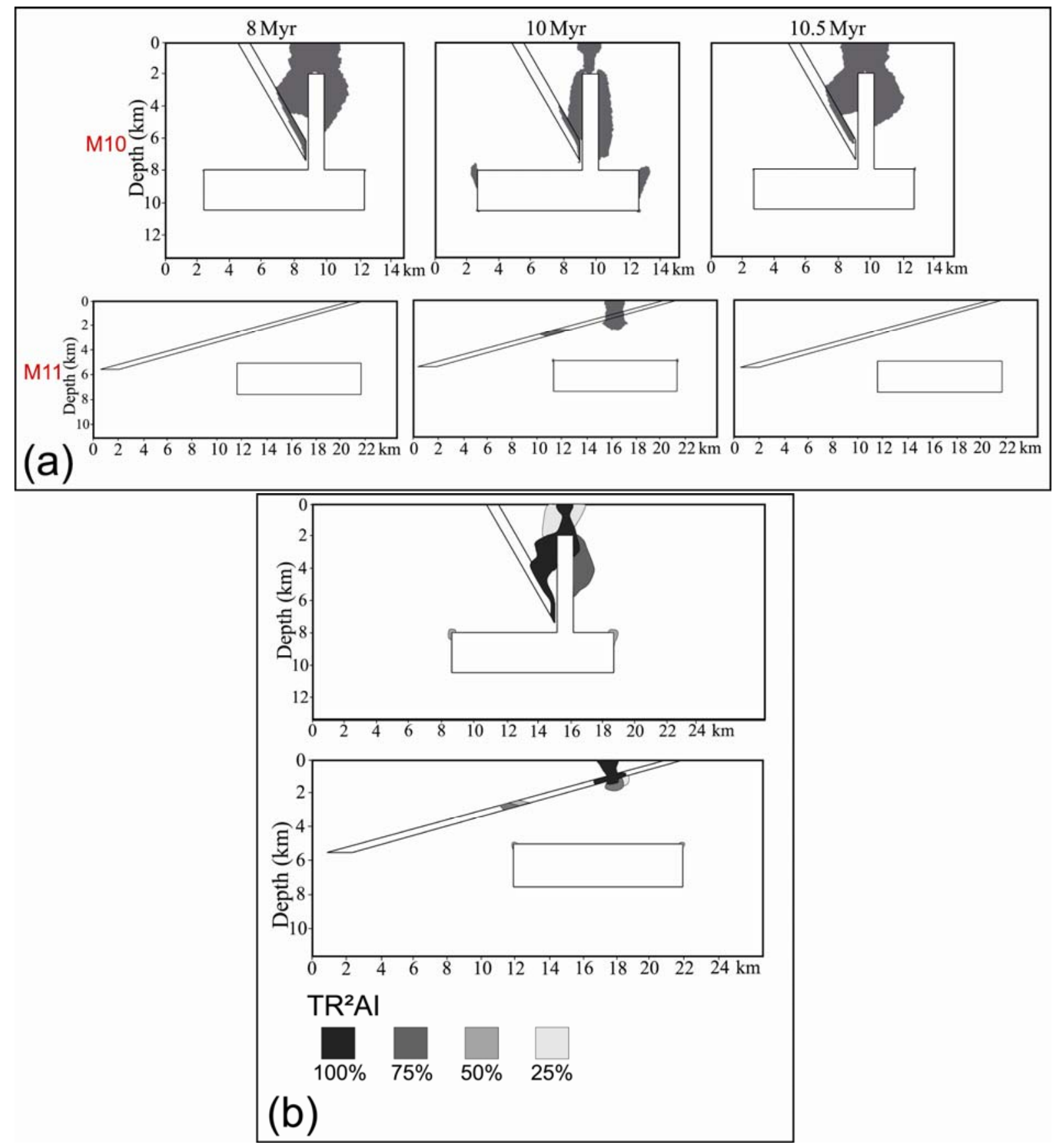




\begin{tabular}{|c|c|c|}
\hline Parameter & Unit & Symbol \\
\hline Fluid velocity & $m \cdot s^{-1}$ & $u$ \\
\hline Permeability & $m^{2}$ & K \\
\hline Dynamic viscosity & Pa.s & $\mu$ \\
\hline Fluid density & $K g \cdot m^{-3}$ & $\rho_{f}$ \\
\hline Fluid pressure & $\mathrm{Pa}$ & $p$ \\
\hline Gravitational acceleration & $m \cdot s^{-2}$ & $\mathrm{~g}$ \\
\hline \multirow{2}{*}{ Depth } & $m$ & $\mathrm{z}$ \\
\hline & $\mathrm{km}$ & $\mathrm{Z}$ \\
\hline Volumetric coefficient of thermal expansion & $K^{-1}$ & $\alpha_{v}$ \\
\hline Weighted average volumetric heat capacity & $J \cdot m^{-3} \cdot K^{-1}$ & $C_{e q}$ \\
\hline Specific heat capacity & $J \cdot \mathrm{kg}^{-1} \cdot K^{-1}$ & $C_{p}$ \\
\hline Thermal conductivity & $W \cdot m^{-1} \cdot K^{-1}$ & $\lambda$ \\
\hline Equivalent thermal conductivity & $W \cdot m^{-1} \cdot K^{-1}$ & $\lambda_{e q}$ \\
\hline General heat source & $W \cdot m^{-3}$ & Q \\
\hline Volumetric heat capacity of moving fluid & $J \cdot m^{-3} \cdot K^{-1}$ & $\mathrm{C}_{\mathrm{L}}$ \\
\hline Temperature & $K,{ }^{\circ} \mathrm{C}$ & $T$ \\
\hline Porosity, (5\% in pluton and host rocks) & - & $\phi$ \\
\hline
\end{tabular}

